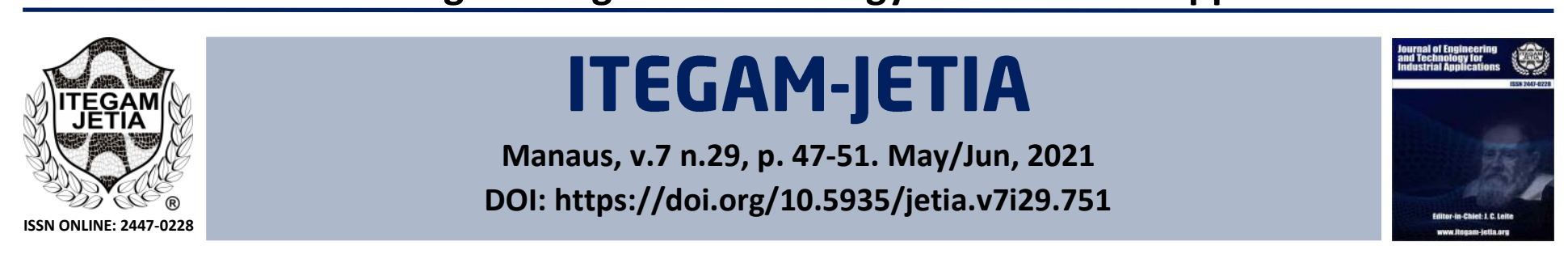

\title{
DETERMINATION OF FACTORS AFFECTING THE CONSUMPTION BEHAVIOR OF ORNAMENTAL PLANT CONSUMERS: ŞANLIURFA SAMPLING OF TURKEY
}

\author{
Mustafa Hakki Aydoğdu*1 and Necla Yildizoğullari \\ ${ }^{1,2}$ Department of Agricultural Economics, Faculty of Agriculture, Harran University. Sanlıurfa, Turkey.
}

${ }^{1}$ http://orcid.org/0000-0002-4945-5239 (10, ${ }^{2}$ http://orcid.org/0000-0001-9372-9068 (i)

Email: *mhaydogdu@ hotmail.com, neclahulagu00@ gmail.com

\begin{tabular}{|c|c|}
\hline ARTICLE INFO & ABSTRACT \\
\hline $\begin{array}{l}\text { Keywords: } \\
\text { Ornamental plants, } \\
\text { Consumer behavior, } \\
\text { Factors affecting consumption, } \\
\text { Şanlıurfa-Turkey. }\end{array}$ & $\begin{array}{l}\text { ornamental plant consumers in Şanliurfa. The material of this research consists of data } \\
\text { obtained from face-to-face surveys with consumers selected by a simple random sampling } \\
\text { method in Şanliurfa, and the surveys were conducted in } 2020 \text {. Multinomial probit, negative } \\
\text { binomial regression, and Tobit models were used in the analyzes. According to the results, } \\
\text { the gender, marital status, income, employment status, and education level of the } \\
\text { participants were determined as effective factors at different statistical significance levels. } \\
\text { It was determined that age is not an effective factor. When the income level rises by one } \\
\text { level, the ornamental plant expenditure increases by } 19.93 \mathrm{TL} \text { annually, and when the } \\
\text { education level rises by one level, it increases by } 17 \mathrm{TL} \text {. The spread of ornamental plant } \\
\text { cultivation should be encouraged in Şanliurfa. This study is the first kind on this subject in } \\
\text { Şanliurfa. }\end{array}$ \\
\hline
\end{tabular}

Copyright (02016 by authors and Galileo Institute of Technology and Education of the Amazon (ITEGAM). This work is licensed under the Creative Commons Attribution International License (CC BY 4.0).

\section{INTRODUCTION}

Plants, especially ornamental plants, have been used as a source of nutrition, food, healing, social and religious ritual, aesthetic, functional, economical, industrial, landscape, decor, morale and motivation, together with the history of humanity until now [1]-[21]. Ornamental plants, which are a sub-branch of crop production in agricultural activities, differ from other agricultural product varieties with their soothing, relaxing, happy, and peaceful results that meet the spiritual and visual needs of people instead of food needs [15]. The term ornamental plants used in agricultural production is an inclusive term and they are collected in four subgroups as cut flowers, potted plants, outdoor and indoor ornamental plants, and natural flower bulbs, and cut flowers have the largest share among ornamental plants in Turkey [16]. Ornamental plants and floriculture is a non-essential necessity item, has become a commercial sector and an important for employment, which is constantly increasing in importance due to its contribution to human psychology, satisfying people's aspirations for the environment, nature, and natural environment in places where industrialization and urbanization are intense [2], [3], [5], [17], [22]. In addition to its positive effects on people due to its aesthetic properties, ornamental plants have become a globally growing sector that softens and improves the physical properties of the place, contributes significantly to the economy and employment with the added value it creates [3]-[5], [8], [12], [17], [19], [21].

Sanliurfa is the most important province in terms of agricultural production potential, which is included in the Southeastern Anatolia Project (GAP). [23]-[25]. Şanlıurfa has an important potential in terms of ornamental plant cultivation due to its geothermal resources and seasonal characteristics, and also has endemic and geophyte varieties peculiar to the region [4], [19], 
[21]. Although Turkey has an important potential in terms of ornamental plants and floriculture, scientific studies in this field are not common enough [1], [3]. The purpose of this study is to determine the factors that affect the consumption behavior of ornamental plant consumers in Şanlıurfa, Turkey.

\section{MATERIALS AND METHODS}

The main material of this research is the data obtained from face-to-face surveys with ornamental plant consumers in Şanlıurfa, and consumers were determined by a simple random sampling method based on voluntary participation. The population of Şanliurfa was 2.12 million people according to the results of the address-based population registration system in 2020 [26]. The sampling volume of the research was determined as 384 according to the table of population sizes and sample volumes according to tolerable sampling error [27], [28] with 95\% confidence limit and $5 \%$ margin of error. To stay on the safe side, 390 surveys based on voluntary participation in the field were conducted in 2020 . The data obtained from the surveys were transferred to Excel, analyzed in SPSS, and interpreted. The average and distribution range of numerical data such as age or income of the participants was determined by performing frequency analyzes based on the research questions. The main analyzes were made by regression analysis. Regression analysis is a statistical method used to determine the relationship between two or more variables. It is used to predict models based on dependent or explained variables, and cumulative normal distribution is used in probit analysis [29], [30]. Multinomial probit analysis was performed to determine the characteristics that distinguish consumers in purchasing ornamental plants and flowers. The number of flowers consumers received and gave during the year was analyzed by negative binomial counting data regression. In the analysis of the consumption of ornamental plants and flowers, the Tobit model, which is widely used to explain models with limited dependent variables, was used. The model is a linear regression model with non-negative dependent variables and is based on variables that do not take negative values such as price, wage, and expenditure [30], [31].

\section{RESULTS AND DISCUSSIONS}

$70 \%$ of the consumers participating in the research were female and $30 \%$ were male. The low number of males in the number of participants is because the research subject was not very interesting by male participants due to the norm culture of the research field. Participants were between the ages of 18 and 70, with an average age of 28.4 years. 53\% of the participants are single, $40 \%$ are married and $7 \%$ are widows or divorced. $41 \%$ of the participants are university graduates, $34 \%$ are high school graduates and $25 \%$ are secondary school and below. $35 \%$ of the participants are salaried employees, $7 \%$ are self-employed, others are non-working, housewives, retired, and students. The monthly income of $37 \%$ of the participants was between 1501 and 5000 Turkish Lira (TL), $17 \%$ of them have an income of $5001 \mathrm{TL}$ or more, and the remaining income was $1500 \mathrm{TL}$ and below (The average of 1 USD was 7.01 TL in 2020). The monthly average income of the participants was determined as 3415 TL. Participants' annual average purchase expenses of ornamental plants and flowers are calculated as approximately $126 \mathrm{TL}$, with a minimum of $10 \mathrm{TL}$ and a maximum of $3500 \mathrm{TL}$. This calculated average value corresponds to 3 per thousand of the monthly income of the consumers and within the solvency. $55 \%$ of the participants buy ornamental plants and flowers only on special occasions and $22 \%$ for celebrations.

The most purchased varieties are indoor ornamental plants, bouquets, and arrangements. Most purchases are on mother's day, and the appearance and meaning of the variety purchased are the most important reasons for selection. In a study conducted in Turkey, it was determined that the most flowers were taken on Valentine's Day and then on mother's day [3]. The most purchased place is flower shops, followed by online purchases. Consumers buy flowers on special occasions (Mother's Day, Father's Day, Valentine's Day, New Year, etc.), regularly, seasonally, and for other reasons (such as birthdays, celebrations, promotions, and motivations). While most flowers are bought on special occasions, the rate of those who receive flowers regularly is $9 \%$. The purchasing frequency of consumers is given in Table 1.

Table 1: Consumers' purchase frequency and distribution of ornamental plants and flowers.

\begin{tabular}{|c|c|c|}
\hline Purchase period & Frequency & \% \\
\hline Only on special occasions & 213 & 54,6 \\
\hline Regularly & 35 & 9,0 \\
\hline Seasonally & 48 & 12,3 \\
\hline Other reasons & 94 & 24,1 \\
\hline Total & 390 & 100,0 \\
\hline
\end{tabular}

Source: Authors, (2021).

Multinomial probit analysis was performed to determine the socio-economic characteristics that distinguish consumers from these aspects. In the analysis, the dependent variable is the frequency of purchasing ornamental plants and flowers and the reference category is other reasons, and the analysis results are given in Table 2.

Table 2: Multinomial probit analysis results.

\begin{tabular}{|c|c|c|c|c|c|}
\hline \multicolumn{2}{|r|}{ Variables } & Coefficient & $\begin{array}{c}\text { Standard } \\
\text { error }\end{array}$ & $\mathbf{t}$ & $\mathbf{p}$ \\
\hline \multirow{6}{*}{  } & Age & 0.006217 & 0.011618 & 0.54 & 0.593 \\
\hline & Married & 0.24683 & 0.22422 & 1.1 & 0.271 \\
\hline & Female & 0.100582 & 0.226898 & 0.44 & 0.658 \\
\hline & Unemployed & $-0.44574 * *$ & 0.217892 & -2.05 & $0.041 * *$ \\
\hline & Income & $-0.21645 * * *$ & 0.081045 & -2.67 & $0.008 * * *$ \\
\hline & Constant & $0.936262 * *$ & 0.397963 & 2.35 & $0.019 * *$ \\
\hline \multirow{6}{*}{ 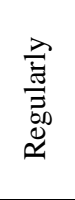 } & Age & 0.013395 & 0.015053 & 0.89 & 0.374 \\
\hline & Married & 0.052466 & 0.293036 & 0.18 & 0.858 \\
\hline & Female & -0.14616 & 0.288534 & -0.51 & 0.612 \\
\hline & Unemployed & $-0.6105 * *$ & 0.306604 & -1.99 & $0.046 * *$ \\
\hline & Income & -0.00767 & 0.10235 & -0.07 & 0.940 \\
\hline & Constant & -0.75833 & 0.514241 & -1.47 & 0.140 \\
\hline \multirow{6}{*}{ 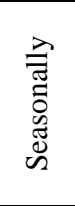 } & Age & 0.015073 & 0.013095 & 1.15 & 0.250 \\
\hline & Married & 0.205916 & 0.265599 & 0.78 & 0.438 \\
\hline & Female & 0.011336 & 0.281147 & 0.04 & 0.968 \\
\hline & Unemployed & 0.098927 & 0.26596 & 0.37 & 0.710 \\
\hline & Income & -0.03515 & 0.097138 & -0.36 & 0.717 \\
\hline & Constant & -0.95262 & 0.48298 & -1.97 & 0.049 \\
\hline
\end{tabular}

Wald chi-square $(15)=23.59 ;$ Log-likelihood $=-434.84773 ; \mathrm{p}=0.0724$.

Shows the statistical level of importance by $* * 5 \%, * * * 1 \%$.

Source: Authors, (2021).

In terms of the multinomial probit model estimation results in Table 2, according to those who bought flowers for other reasons:

- Employees are more likely to buy flowers "only on special occasions".

- The higher the income, the more likely it is to buy flowers "only on special occasions".

- Employees are more likely to purchase flowers "regularly". 
The results of marginal effects of the multinomial probit model estimation are given in Table 3 .

Table 3: Marginal effects of multinomial probit model estimation.

\begin{tabular}{|l|c|c|c|c|}
\hline \multicolumn{1}{|c|}{ Variables } & $\begin{array}{c}\text { Only on special } \\
\text { occasions }\end{array}$ & Regularly & Seasonally & $\begin{array}{c}\text { Other } \\
\text { reasons }\end{array}$ \\
\hline Age & 0.000 & 0.001 & 0.002 & -0.002 \\
\hline Married & 0.054 & -0.014 & 0.010 & -0.050 \\
\hline Female & 0.039 & -0.025 & -0.004 & -0.010 \\
\hline Unemployed & $-0.104^{*}$ & -0.050 & $0.068^{*}$ & $0.086^{*}$ \\
\hline Income & $-0.063^{* * *}$ & 0.014 & 0.013 & $0.035^{* *}$ \\
\hline
\end{tabular}

Shows the statistical level of importance by $* 10 \%, * * 5 \%$

Source: Authors, (2021).

According to the marginal effects in Table 3:

- Employees are $10.4 \%$ more likely to buy flowers only on special occasions than non-employees.

- Unemployed are $6.8 \%$ more likely to purchase flowers seasonally than employees.

- Those who do not work are $8.6 \%$ more likely to buy flowers for other reasons than employees.

- When income increases by one unit, the probability of buying flowers only on special occasions decrease by $6.3 \%$.

- When income increases by one unit, the probability of buying flowers for only other reasons increases by $3.5 \%$.

The number of flowers that consumers receive throughout the year has been analyzed by negative binomial counting data regression, and the results are shown in Table 4. Alpha testing confirms that negative binomial regression should be used instead of using Poisson regression. It is observed that the number of flowers received by the participant is higher in females than in males, less in unemployed than in employees, and more in married than unmarried. Age, education level, and income level do not affect the number of flowers that the consumer receives.

Table 4: Negative binomial regression estimation results (Dependent variable: Number of flowers received).

\begin{tabular}{|l|c|c|c|c|c|}
\hline Variables & Coefficient & $\begin{array}{c}\text { Standard } \\
\text { error }\end{array}$ & $\mathbf{t}$ & $\mathbf{p}$ & $\begin{array}{c}\text { Marginal } \\
\text { effect }\end{array}$ \\
\hline Age & -0.01096 & 0.006963 & -1.57 & 0.115 & -0.0390685 \\
\hline $\begin{array}{l}\text { Education } \\
\text { Level }\end{array}$ & -0.04410 & 0.054033 & -0.82 & 0.414 & -0.1571822 \\
\hline Income & 0.043754 & 0.053289 & 0.82 & 0.412 & 0.1559676 \\
\hline Female & 0.398642 & 0.137064 & 2.91 & $0.004 * * *$ & 1.321226 \\
\hline Unemployed & -0.639790 & 0.131522 & -4.86 & $0.000^{* * *}$ & -2.117342 \\
\hline Married & 0.315144 & 0.129026 & 2.44 & $0.015^{* *}$ & 1.164704 \\
\hline _constant & 1.488746 & 0.331726 & 4.49 & $0.000^{* * *}$ & \\
\hline /lnalpha & 0.048980 & 0.091881 & & & \\
\hline alpha & 1.050199 & 0.096494 & & & \\
\hline LR & & & & \\
\hline
\end{tabular}

LR test of alpha $=0$; chibar2 $(01)=1133.40 ;$ Prob $>=$ chibar $2=0.000$

Shows the statistically level of importance by $* * 5 \%, * * * 1 \%$.

Source: Authors, (2021).

According to the marginal effect values in Table 4:

- Females receive 0.39 more flowers than males.

- An employee receives 0.64 fewer flowers than a nonemployee.

- Married people receive 0.39 more flowers than unmarried ones.

The number of flowers given by consumers throughout the year has also been analyzed by negative binomial counting data regression, and the results are given in Table 5. The alpha test concluded that negative binomial regression should be used. The number of flowers given is less in females than in males, more in those who are married than in those who are not married, and in those who are not working, less than in those who work. The number of flowers given does not differ in terms of age, education level, and income level.

Table 5: Negative binomial regression estimation results (Dependent variable: Number of flowers received).

\begin{tabular}{|l|c|c|c|c|c|}
\hline \multicolumn{1}{|c|}{ Variables } & Coefficient & $\begin{array}{c}\text { Standard } \\
\text { error }\end{array}$ & $\mathbf{t}$ & $\mathbf{p}$ & $\begin{array}{c}\text { Marginal } \\
\text { effect }\end{array}$ \\
\hline Age & -0.008540 & 0.007475 & -1.14 & 0.253 & -0.0085429 \\
\hline $\begin{array}{l}\text { Education } \\
\text { Level }\end{array}$ & 0.009947 & 0.056078 & 0.18 & 0.859 & 0.0099469 \\
\hline Income & 0.082996 & 0.052858 & 1.57 & 0.116 & 0.0829955 \\
\hline Female & -0.163360 & 0.134669 & -1.21 & 0.225 & -0.1633629 \\
\hline Unemployed & -0.633110 & 0.136186 & -4.65 & $0.000^{* * *}$ & -0.6331074 \\
\hline Married & 0.293222 & 0.134053 & 2.19 & $0.029^{* *}$ & 0.2932222 \\
\hline _constant & 1.626030 & 0.345427 & 4.71 & $0.000^{* * *}$ & 1.62603 \\
\hline /lnalpha & 0.129022 & 0.086675 & & & \\
\hline alpha & 1.137715 & 0.098611 & & & \\
\hline
\end{tabular}

LR test of alpha $=0 ;$ chibar2 $(01)=1485.12 ;$ Prob $>=$ chibar $2=0.000$

Shows the statistically level of importance by $* * 5 \%$, *** $1 \%$.

Source: Authors, (2021).

According to the marginal effect values in Table 5:

- Females give 0.16 fewer flowers than males.

- The employee gives 0.63 fewer flowers than the unemployed.

- Married people give 0.29 more flowers than unmarried ones.

The Tobit model was used to determine the consumer characteristics that determine the annual flower expenditure, and the results are given in Table 6. Consumers with zero flower spending prevent the linear regression to meet the "neutrality of estimators" condition. For this reason, the Tobit model, which is suitable for situations where the dependent variable can also take the value of 0 , is used.

Table 6. Tobit model estimation results (Dependent variable: Flower expenditure).

\begin{tabular}{|l|c|c|c|c|c|}
\hline Variables & Coefficient & $\begin{array}{c}\text { Standard } \\
\text { error }\end{array}$ & $\mathbf{t}$ & $\mathbf{p}$ & $\begin{array}{c}\text { Marginal } \\
\text { effect }\end{array}$ \\
\hline Constant & -74.9356 & 79.6677 & -0.9406 & 0.3469 & \\
\hline Age & 1.13181 & 1.59777 & 0.70840 & 0.4787 & 0.73997 \\
\hline Income & $30.4797^{* * *}$ & 11.4958 & 2.65100 & $0.0080^{* * *}$ & 19.927 \\
\hline Married & 21.1025 & 31.1717 & 0.6770 & 0.4984 & 13.860 \\
\hline Female & -17.8489 & 31.1998 & -0.5721 & 0.5673 & -12.072 \\
\hline Unemployed & -46.6962 & 30.5238 & -1.530 & 0.1261 & -30.571 \\
\hline $\begin{array}{l}\text { Education } \\
\text { level }\end{array}$ & $26.0066^{* *}$ & 12.6644 & 2.0540 & $0.0400^{* *}$ & 17.003 \\
\hline Sigma & 262.343 & 10.0887 & & & \\
\hline Constant & -74.9356 & 79.6677 & -0.9406 & 0.3469 & \\
\hline Show the
\end{tabular}

Shows the statistical level of importance by $* * 5 \%, * * * 1 \%$.

Source: Authors, (2021).

According to the Tobit model estimation results, as income and education level increase, flower expenditure increases. According to the marginal impact values, when the income category rises by one level, flower expenditure increases by 19.93 
TL annually and $17 \mathrm{TL}$ when the education category rises by one level.

\section{CONCLUSIONS}

Ornamental plants have started to be among the noncompulsory but widely preferred needs that people are increasingly paying attention to due to reasons such as population growth, urbanization, and industrialization. According to the results of the research, while the ornamental plants and flowers of the consumers participating in the survey were at most $54.6 \%$ on special occasions, the rate of those who buy them regularly was $9 \%$. According to the multinomial probit model estimation results, employees' probability of getting flowers "only on special occasions" increases $(\mathrm{p}<5 \%)$. The higher the income, the higher the probability of getting flowers "only on special occasions" $(\mathrm{p}<1 \%)$. Employees are more likely to buy flowers "regularly" $(\mathrm{p}<5 \%)$. In terms of marginal effects, employees are $10.4 \%$ more likely to buy flowers only on special occasions than non-employees. Nonworking people are $6.8 \%$ more likely to purchase flowers seasonally than employees, and $8.6 \%$ more likely to purchase flowers for other reasons. When income increases by one unit, the probability of purchasing flowers only on special occasions decrease by $6.3 \%$, while the probability of purchasing flowers increases by $3.5 \%$ for other reasons. It is seen that the number of receive flowers is higher in women than in men $(\mathrm{p}<5 \%)$, less in non-working than in employees $(\mathrm{p}<1 \%)$, and more in married than in unmarried $(\mathrm{p}<5 \%)$. Age, education level, and income level do not affect the number of flowers received ( $p>10 \%)$. According to the marginal effect values, women received 0.39 more flowers than men, 0.64 fewer than non-employed, and 0.39 more flowers than unmarried women. The number of flowers given is less in women than in men, more in those who are married than in those who are not married, and in those who are not working, less than in those who work. The number of flowers given does not differ in terms of age, education level, and income level ( $p>10 \%$ ). According to the marginal effect values, females give 0.16 more flowers than males, employees 0.63 less than unemployed and married ones give 0.29 more flowers than unmarried ones. According to the model estimation results of ornamental plant and flower expenditures, as income and education level increase, flower expenditure increases. According to the marginal impact values, when the income level rises by one level, flower expenditure increases by $19.93 \mathrm{TL}$ annually and 17 TL when the education level rises by one level.

Şanlıurfa has an important potential for growing ornamental plants due to its endemic and geophyte varieties and seasonal characteristics. The widespread use of ornamental plant cultivation in Şanliurfa should be encouraged due to the foresight that the prices will decrease with the widespread production and therefore the consumption amount will increase among consumers. This study is the first study on this subject in Şanlıurfa. This study was derived from the master's thesis entitled "Determination of Ornamental Plants Potential: The Case of Şanlıurfa Province" completed by the second author under the supervision of the corresponding author.

\section{AUTHOR'S CONTRIBUTION}

Conceptualization: Mustafa Hakkı Aydoğdu and Necla Yıldızoğulları.

Methodology: Mustafa Hakkı Aydoğdu.

Investigation: Mustafa Hakkı Aydoğdu and Necla Yıldızoğulları. Discussion of results: Mustafa Hakkı Aydoğdu and Necla Yıldızoğulları.
Writing - Original Draft: Mustafa Hakkı Aydoğdu and Necla Yıldızoğulları.

Writing - Review and Editing: Mustafa Hakkı Aydoğdu.

Resources: Mustafa Hakkı Aydoğdu and Necla Yıldızoğulları. Supervision: Mustafa Hakkı Aydoğdu.

Approval of the final text: Mustafa Hakkı Aydoğdu and Necla Y1ldızoğulları.

\section{REFERENCES}

[1] H. S. Akduman, “İzmit’teki park ve bahçelerde yetiştirilen süs bitkileri,” Yüksek Lisans Tezi, Kocaeli Üniversitesi Fen Bilimleri Enstitüsü, Koaeli, Türkiye, 2014

[2] S. Ay, "Süs bitkileri ihracatı, sorunları ve çözüm önerileri: Yalova ölçeğinde bir araştırma," Süleyman Demirel Üniversitesi İktisadi ve İdari Bilimler Fakültesi Dergisi, vol. 14, no. 3, pp. 423-443, 2009.

[3] K. Aydinşakir, B. Sayın, M. A. Çelikyurt, and Ö. Karagüzel, “Antalya ili kesme çiçek perakendeciliğinin analizi," Akdeniz Üniversitesi Ziraat Fakültesi Dergisi, vol. 27 , no. 2 , pp. 75-82, 2016.

[4] M. H. Aydoğdu and N. Yıldızoğulları, "Şanlıurfa'ki süs bitkileri üreticilerinin mevcut yapıları ve sektöre bakışları üzerine bir araştırma," Journal of Disciplines Economics \& Administrative Sciences Studies, vol. 7, no. 28, pp. 313-321, 2021.

[5] Y. Bulut, E. Akpınar, and H. Yılmaz, "Erzurum kentinin kesme çiçek tüketim potansiyelinin belirlenmesi ve çözüm önerileri," GOÜ Ziraat Fakültesi Dergisi, vol. 24, no. 2, pp. 7-11, 2007.

[6] M. Cançelik, "A field research on the medical aromatic plant selling enterprises (Aktar/Attar) in Şanllurfa," in Current Researches in Economics and Administrative Sciences, Y. A. Unvan and İ. Serbestoğlu, Eds. Cetinje-Montenegro: Ivpe Cetinje, 2020, pp. 25-48.

[7] B. Cengiz, M. Sabaz, and M. Sarıbaş, "The use of some natural crataegus L. (Hawthorn) taxa from western Black Sea Region of Turkey for landscape applications," Fresenius Environmental Bulletin, vol. 20, no. 3, pp. 938-946, 2011.

[8] B. Cengiz, P. K. Dağlı, and S. Yiğittekin, "Peyzaj ekonomisi açısından peyzaj ve süs bitkileri fidanlık işletmelerine yönelik sektörel bir analiz," Bartın Orman Fakültesi Dergisi, vol. 19, no. 2, pp. 50-62, 2017.

[9] D. Ciçekdemir, "Türkiye'deki süs bitkileri pazar payının arastırılması: Bursa ili örneğinde," Yüksek Lisans Tezi, Namık Kemal Üniversitesi Fen Bilimleri Enstitüsü, Tekirdağ, Türkiye, 2010.

[10] A. Eşitken, Y. Çelik, A. T. Polat, and Z. Karakayacı, "Konya'da dış mekân süs bitkileri, iç mekân süs bitkileri, kesme çiçekler ve çiçek soğanları yetiștiriciliğ yatırımlarına yönelik çalışması,” 2012. https://www.kalkinmakutuphanesi.gov.tr/assets/upload/dosyalar/dsyfme8f4720201 712200pm.pdf (accessed May 05, 2021).

[11] B. Gençer, "Dünya'da ve Türkiye'de kesme çiçek sektörü pazarlama organizasyonları ve tüketici eğilimleri,” Doktora Tezi, Namık Kemal Üniversitesi Fen Bilimleri Enstitüsü, Tekirdağ, Türkiye, 2014.

[12] O. Karagüzel et al., Sekizinci beş yıllık kalkınma planı bitkisel üretim özel ihtisas komisyonu (süs Bitkileri alt komisyon raporu). Ankara,Turkey: DPT: 2645ÖIK:653, 2000.

[13] M. K. Kıymaz, "Dış mekân süs bitkileri üretim işletmelerinde maliyetleme ve raporlama," Doktora Tezi, Sakarya Üniversitesi Sosyal Bilimler Enstitüsü, Sakarya, Türkiye, 2017.

[14] İ. Kızılkan, “Türkiye'de süs bitkileri üretim ve pazarlama sektörünün sorunlar ve çözüm önerileri," Yüksek Lisans Tezi, Ankara Üniversitesi Fen Bilimleri Enstitüsü, Ankara,Türkiye, 2016.

[15] H. A. Onay, “Türkiye'de süs bitkileri üretim ve pazarlama sektörünün sorunlar ve çözüm önerileri,” Doktora Tezi, Ankara Üniversitesi Fen Bilimleri Enstitüsü, Ankara,Türkiye, 2008.

[16] İ. Özkan, "Süs bitkileri yetiștiriciliğinde damla sulama uygulamalarında karşılaşılan sorunlar ve çözüm önerileri," Yüksek Lisans Tezi, Namık Kemal Üniversitesi Fen Bilimleri Enstitüsü, Tekirdağ, Türkiye, 2009. 
[17] (SÜSBİR) Süs Bitkileri Üreticileri Birliği, "Süs bitkileri sektör raporu," 2019. http://www.susbir.org.tr/yeni/belgeler/raporlar/susbir-sektor-raporu-2019.pdf (accessed May 04, 2021).

[18] M. Temel, "Yalova'da süs bitkileri işletmelerinin yapısı, üretim olanakları, sorunları ve çözüm önerileri," Yüksek Lisans Tezi, Namık Kemal Üniversitesi Fen Bilimleri Enstitüsü, Tekirdağ, Türkiye, 2011.

[19] İ. H. Ünlü, "Şanlıurfa kent dokusuna uygun karasal iklim koşullarına dayanıklı çok yıllık süs bitkilerinin belirlenmesi," Yüksek Lisans Tezi, Mustafa Kemal Üniversitesi Fen Bilimleri Enstitüsü, Hatay, 2014.

[20] K. Yazıcı, "Tokat ili ekolojik koşullarında dıș mekân süs bitkileri sektör analizi ve uygun üretim alanlarının CBS ile belirlenmesi,” Doktora Tezi, Ege Üniversitesi Fen Bilimleri Enstitüsü, İzmit, Türkiye, 2015.

[21] N. Yıldızoğulları, "Süs bitkileri potansiyelinin belirlenmesi: Şanlıurfa ili örneği," Yüksek Lisans Tezi, Harran Üniversitesi Fen Bilimleri Enstitüsü, Şanlıurfa, Türkiye, 2020.

[22] A. Çelik, E. Torun, and A. Bobat, "Süs bitkilerine ilgi gösteren kişilerin genel profilin belirlenmesi," Erdemli-Mersin, Türkiye, Oct. 2010, pp. 339-347.

[23] M. H. Aydoğdu, "Evaluation of willingness to pay for irrigation water: Harran Plain sampling in GAP region -Turkey," Applied Ecology and Environmental Research, vol. 14, no. 1, pp. 349-365, 2016.

[24] G. Sevinç, M. H. Aydoğdu, M. Cançelik, and M. R. Sevinç, "Farmers' attitudes toward public support policy for sustainable agriculture in GAP-Şanlıurfa, Turkey," Sustainability, vol. 11, no. 23, p. 6617, 2019.

[25] H. P. Doğan, M. H. Aydoğdu, M. R. Sevinç, and M. Cançelik, "Farmers' willingness to pay for services to ensure sustainable agricultural income in the GAPHarran Plain, Şanlıurfa, Turkey,” Agriculture, vol. 10, no. 5, p. 152, May 2020.

[26] TURKSTAT, "Adrese dayalı nüfus kayıt sistemi sonuçları, 2020," 2021. https://data.tuik.gov.tr/Bulten/Index?p=Adrese-Dayali-Nufus-Kayit-Sistemi-

Sonuclari-2020-37210 (accessed May 05, 2021).

[27] Y. Yazıcıŏlu and S. Erdoğan, SPSS uygulamalı bilimsel araştırma yöntemleri. Ankara, Türkiye: Detay Yayıncılık, 2014.

[28] N. Bayram, Sosyal bilimlerde SPSS ile ileri veri analizi. Ankara, Türkiye: Ezgi Kitapevi, 2014.

[29] Ş. Kalayc1, SPSS Uygulamalı çok değişkenli istatistik teknikleri. Ankara, Türkiye: Asil Yayın Dağıtım, 2014.

[30] M. Mert, SPSS STATA yatay kesit veri analizi bilgisayar uygulamalart. Ankara: Detay Yayıncilık, 2016.

[31] Ş. Koç and M. Şahin, "Tobit model ve bir uygulama," KSÜ Doğa Bilimleri Dergisi, vol. 21, no. 1, pp. 73-80, 2018. 